\title{
Influence of a complex preparation based on phytoextracts on productivity indicators and development of the immune organs of broiler- type chicken
}

\author{
Elena Shatskikh ${ }^{1,}$, Alena Nufer $^{1}$, Danis Galiev ${ }^{1}$, and Irina Rogozinnikova ${ }^{1}$ \\ ${ }^{1}$ Ural State Agrarian University, Department of Zoological Engineering, 620075 Yekaterinburg, Russia
}

\begin{abstract}
This research is devoted to studying the safety of livestock, live weight, mass of internal organs and morphohistological changes in the immune organs of broiler-type chicken when substituting antibiotic feed supplements in the diet and in combination with antibiotic growth stimulants, a feed additive including essential oils, protected organic acids (fumaric acid, sorbic acid, DL-malic acid, citric acid), and hot pepper extract. The experimental procedure was conducted at the production conditions of "Ptitsefabrika "Sredneuralskaya" OOO in broiler-type chicken "Ross 308" under the guidelines of the Federal Research Center "VNITIP" of the Russian Academy of Sciences (2013). Having conducted research, the positive effect of a complex preparation based on phytoextracts on the liveability of broiler-type chicken, their live weight, and on the development of the immune organs was determined.
\end{abstract}

\section{Introduction}

Lack of efficacy of antibiotics in poultry breeding is indicated by many researchers. It is emphasized that the tough environmental situation and unbalanced nutrition promote the spread of intestinal infections in poultry plants: salmonellosis, colibacteriosis, listeriosis. Antibiotics usage becomes ineffective and environmentally detrimental [1].

A WHO report, released in April 2014, noted that "this serious threat is no longer a prediction for the future. Antibiotic resistance-when bacteria change so antibiotics no longer work in people who need them to treat infections-is now a major threat to public health" [2]. Misuse of antibiotics in breeding is a contributing factor to the emergence and spread of antibiotic-resistant micro-organisms. It is essential to limit the antibiotic use as a growth promoter in animal feed. [3].

An optimal combination of different options to feed antibiotics in combination with good management methods will be the key to keep productivity of animals $[4,5,6,7]$.

Flexible responses to market changes ensure a smooth and timely switch from antibiotics to advanced technologies [8]. In current poultry breeding, many feed additives can replace growth-promoting antibiotics in the diet of animals $[9,10]$.

\footnotetext{
* Corresponding author: evshackih@yandex.ru
} 
The mixture of phytoextracts, essential oils and protected organic acids has a complex growth-promoting effect on the animal's body and, among other things, increases feed appeal, has anti-stress effect, and accumulates the secretion of saliva and digestive enzymes [11].

The objective of the research was to analyze livability indicators, live weight, feed conversion of broiler-type chicken, as well as the mass of organs forming the immune system and morphohistological changes in these organs when replacing feed antibiotic in the compound feed and with the additional introduction of a complex preparation including components with pronounced growth-promoting features: phytobiotics, protected organic acids, and essential oils.

\section{Materials and Methods}

The experimental procedure was conducted in 2019 at the production conditions of "Ptitsefabrika "Sredneuralskaya" OOO in broiler-type chicken "Ross 308".

Groups were formed for research and economic experience, as well as the academic basis of the research was implemented under the guidelines of the Federal Research Center "VNITIP" of the Russian Academy of Sciences (2013) (tab.1).

Table 1. Research and economic experiment scheme

\begin{tabular}{|c|c|c|}
\hline Groups & $\begin{array}{l}\text { Number of } \\
\text { animal units }\end{array}$ & Feeding conditions \\
\hline Control group & $\begin{array}{l}180 \\
+80\end{array}$ & $\begin{array}{l}\text { Basic diet consisted of all-in-one feed with food power } \\
\text { meeting the guidelines for cross. } \\
\text { Basic diet included in-feed antibiotic: } \\
\text { from day } 1 \text { to day } 21 \text {-Albacin in the amount of } 300 \mathrm{~g} / \mathrm{t} \\
\text { of animal feed and from the } 22 \mathrm{nd} \text { to the } 30 \mathrm{th} \text { day } \\
\text { Nozygeptide }-250 \mathrm{~g} / \mathrm{t} \text { of animal feed }\end{array}$ \\
\hline $\begin{array}{l}1 \text { experimental } \\
\text { group }\end{array}$ & $\begin{array}{l}\$ 80 \\
+80\end{array}$ & $\begin{array}{l}\text { Basic diet }+ \text { studied additive in the amount of } 1 \mathrm{~kg} / \mathrm{t} \text { of } \\
\text { animal feed. } \\
\text { Usage period: from day } 1 \text { to the end of fattening }\end{array}$ \\
\hline $\begin{array}{c}2 \text { experimental } \\
\text { group }\end{array}$ & $\begin{array}{l}780 \\
+80\end{array}$ & $\begin{array}{l}\text { Experimental diet: in-feed antibiotic in basic diet в OP } \\
\text { replaced with the studied additive in the amount of } 1 \mathrm{~kg} / \\
\text { t of animal feed. } \\
\text { Usage period: from day } 1 \text { to the end of fattening. }\end{array}$ \\
\hline
\end{tabular}

During the experiment, the livability of animal units and live weight of poultry were considered. At the end of fattening (38 days), 3 broiler-type chicken were chosen from each experimental group, followed by determination (after slaughter) of spleen mass, bursa of Fabricius, and morphohistological analyses. Material for studying the general structural changes in organs was recorded in a $10 \%$ solution of neutral formalin, paraffin sections were prepared, and the samples were stained with hematoxylin and eosin according to the generally accepted method. All histological studies were documented by taking photographs using a Leica microscope.

Major experimental data were treated by the method of variational statistics using Microsoft Excel. The statistical significance of differences between groups was estimated using the Student's test.

\section{Results and Discussion}

Table 2 presents zootechnical indicators of broiler-type chicken according to the findings of research and economic experiment. 
Table 2. Zootechnical indicators of broiler-type chicken

\begin{tabular}{|l|c|c|c|}
\hline \multicolumn{1}{|c|}{ Indicator } & \multicolumn{3}{|c|}{ Groups } \\
\cline { 2 - 4 } & Control group & $\begin{array}{c}1 \text { experimental } \\
\text { group }\end{array}$ & $\begin{array}{c}2 \text { experimental } \\
\text { group }\end{array}$ \\
\hline $\begin{array}{l}\text { Livability (average for roosters and } \\
\text { hens), \% }\end{array}$ & 93,15 & 94,4 & 94,4 \\
\hline $\begin{array}{l}\text { Live weight of poultry at 38 days, g } \\
\text {-broiler roosters } \\
\text { - broiler hens }\end{array}$ & $2149,5 \pm 35,34$ & $2165,6 \pm 28,90$ & $2259,0 \pm 36,08^{*}$ \\
& $1911,4 \pm 26,01$ & $1922,0 \pm 26,10$ & $\begin{array}{c}2027,4 \pm 31,59^{*} \\
*\end{array}$ \\
\hline
\end{tabular}

Notes: *- $P \leq 0,05 ; *_{-} P \leq 0,01$

As can be seen from the information in table 2, the use of the studied additive together with the in-feed antibiotic and alternatively as part of the animal feed, contributed to an accumulating $1.25 \%$ increase in the livability of the poultry units in both experimental groups.

Administration of the drug based on phytobiotics and protected organic acids was followed by an increase in the live weight of poultry. So, the roosters of the 1 st experimental group outperformed the control analogues by $0.7 \%$, and the specimens of the 2 nd experimental group significantly outperformed the control by $5.1 \%(\mathrm{P} \leq 0.05)$. The live weight of hens of the 1 st experimental group was higher than the control by $0.6 \%$, and the representatives of the 2 nd experimental group had a significant excess of $6.1 \%(\mathrm{P} \leq 0.001)$.

The mass of the studied internal organs of broiler-type chicken at the age of 38 days corresponded to physiological norms, while the following differences were seen between the groups (table 3 ).

Table 3. Mass of internal organs of 38-days old broiler-type-chicken $(M \pm m),(n=3)$

\begin{tabular}{|l|c|c|c|}
\hline \multirow{2}{*}{ Name of the organ } & \multicolumn{3}{c|}{ Group } \\
\cline { 2 - 4 } & $\begin{array}{c}\text { Control } \\
\text { group }\end{array}$ & $\begin{array}{c}1 \text { experimental } \\
\text { group }\end{array}$ & $\begin{array}{c}2 \text { experimental } \\
\text { group }\end{array}$ \\
\hline The mass of the spleen, $\mathrm{g}$ & $2,7 \pm 0,43$ & $2,46 \pm 0,27$ & $3,09 \pm 0,78$ \\
\hline Relative weight of the spleen, \% & 0,13 & 0,115 & 0,138 \\
\hline Weight of bursa of Fabricius, $\mathrm{g}$ & $1,17 \pm 0,38$ & $0,96 \pm 0,08$ & $1,02 \pm 0,24$ \\
\hline The relative weight of bursa of Fabricius, \% & 0,055 & 0,045 & 0,046 \\
\hline
\end{tabular}

The spleen weight was the highest in chickens of the 2nd experimental group, being 3.09 $\mathrm{g}$, which outweighs the control value by $0.39 \mathrm{~g}$. In 1 experimental group, this indicator was $0.24 \mathrm{~g}$ lower than the control. The relative weight of this organ in the experimental groups of broilers was in the range of $0.115-0.138 \%$.

Weight of bursa of Fabricius in chickens in experimental groups was in the limits of 0.96$1.17 \mathrm{~g}$, and the relative weight - at the level of $0.045-0.055 \%$.

A morphohistological study revealed that single lymphoid follicles were detected in the spleen of broiler-type chicken of the control group, which signifies a state of immunodeficiency (Fig. 1). 


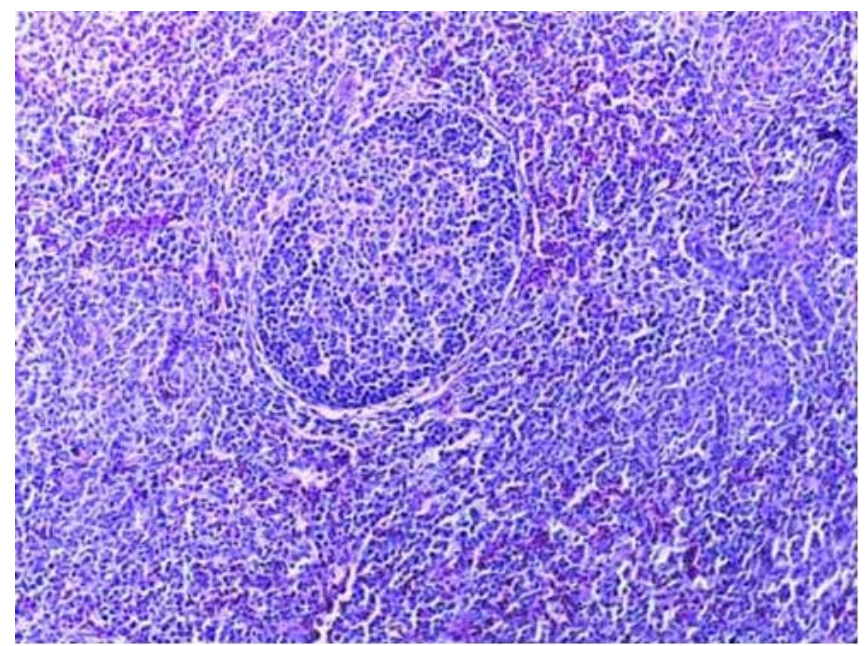

Fig. 1. The spleen of the poultry of the 38-day-old control group Hematoxylin and eosin stain. 200x magnification.

In the spleen of chickens of the 1st experimental group, the activation processes of the formation of lymphoid follicles were identified (Fig. 2).

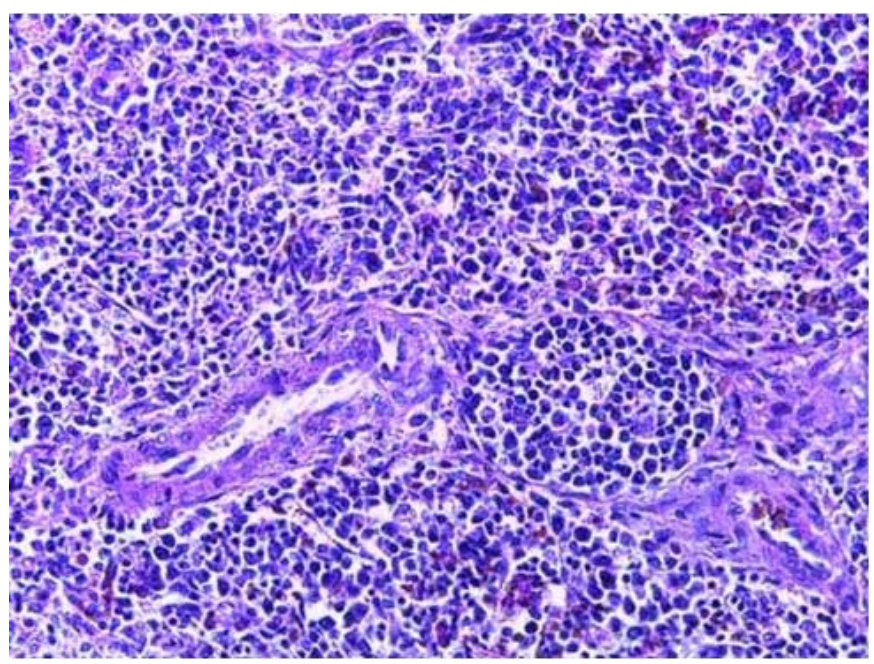

Fig. 2. Spleen of a 38-day-old poultry of the 1 st experimental group Hematoxylin and eosin stain. 200x magnification.

Spleen follicles of the poultry of the 2nd experimental group were clearly contoured and activated (Fig. 3). 


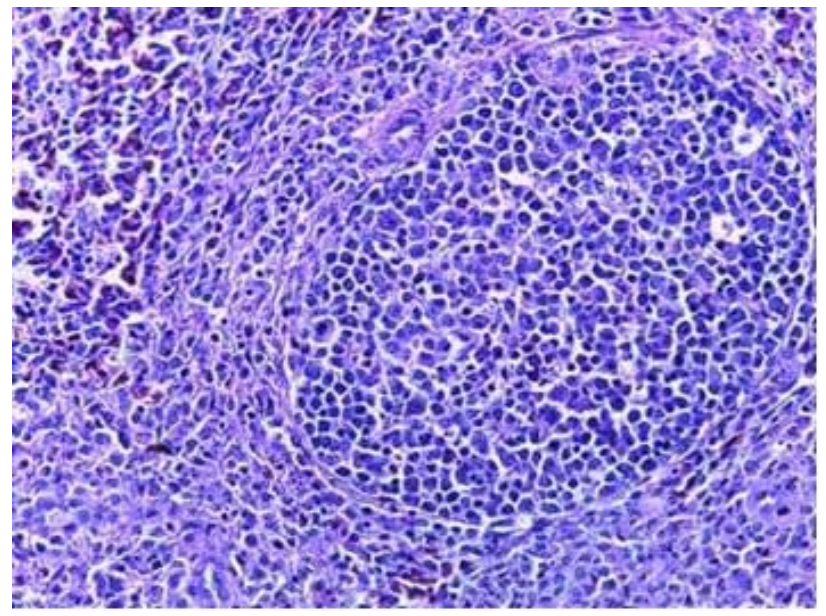

Fig. 3. Spleen of a 38-day-old poultry of the $2^{\text {nd }}$ experimental group Hematoxylin and eosin stain. 200x magnification.

Activation of lymphoid follicles in the 1 st and 2 nd experimental groups may show an increase in the cellular and humoral immune response of poultry.

Bursa of Fabricius of the control group was characterised by a condition of moderate involution (fig.4).

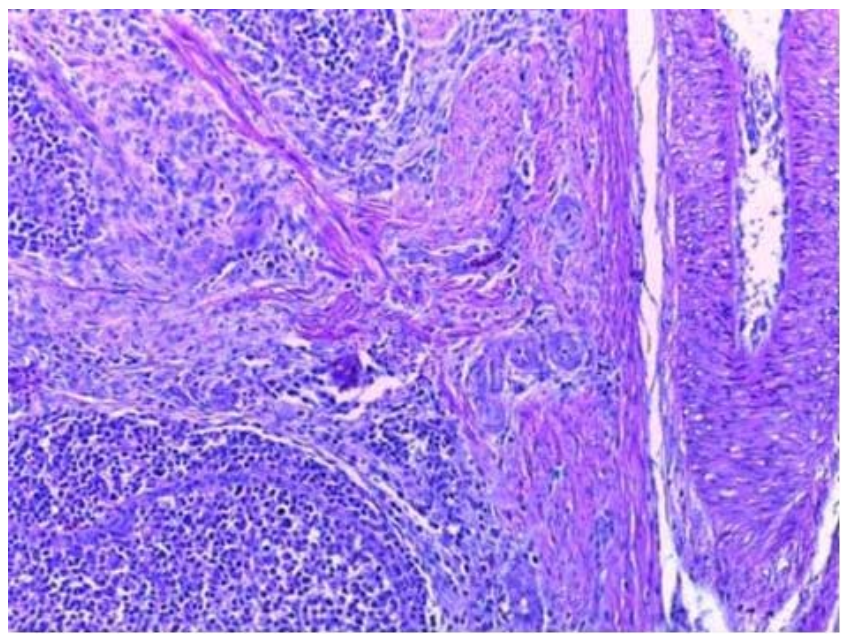

Fig. 4. Bursa of Fabricius of 38-day-old control group poultry Hematoxylin and eosin stain. 200x magnification.

Bursa of Fabricius of poultry of 1st experimental group were at the beginning of the involution processes (fig.5). 


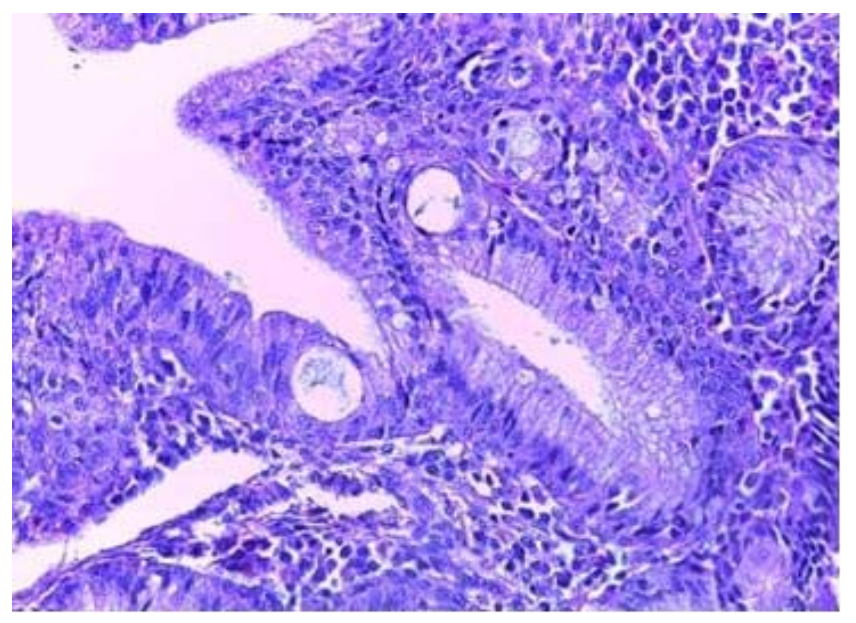

Fig. 5. Bursa of Fabricius of poultry of the 1st experimental group of 38-day age Hematoxylin and eosin stain. 200x magnification.

In the bursa of Fabricius of broilers of the 2nd experimental group were seen weakly expressed processes of involution while conserving the structure of the organ (fig. 6).

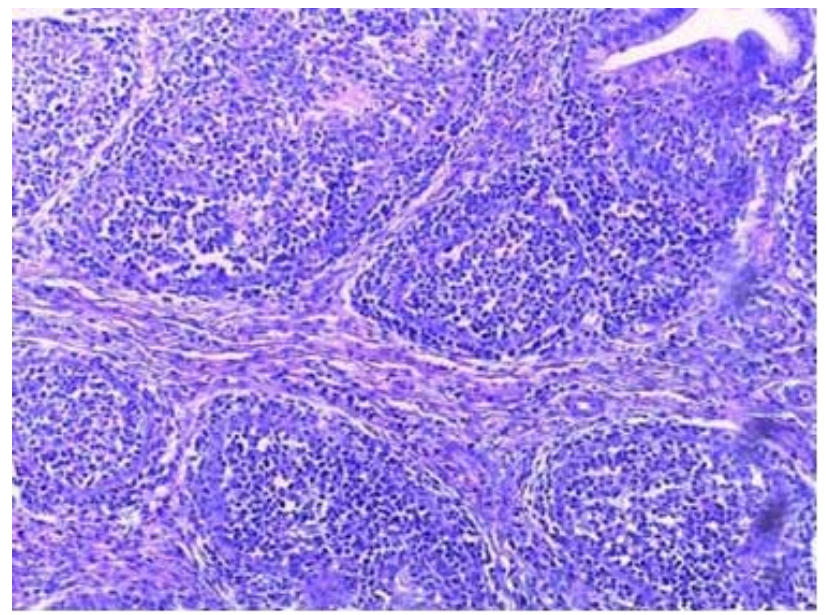

Fig. 6. Bursa of Fabricius of poultry of the 2nd experimental group of 38-day age Hematoxylin and eosin stain. 200x magnification.

\section{Conclusion}

Therefore, the feed additive, which is a mixture of phytoextracts, essential oils and protected organic acids, may be used as a safe alternative to growth-promoting feed antibiotics, as well as as an additional feed component of the diet of broiler-type chicken. Evidence for this is an improvement in the safety of the poultry units and its live weight, on the background of activation of lymphoid follicles in the spleen and weakly expressed involution processes in the bursa of Fabricius signifying strengthening of the cellular and humoral immune response of the poultry. We believe that these changes are due to biologically active compounds that are part of the feed factor under investigation. Essential oils and carvaclol, thymol and eugenol in them, due to their antibacterial, anti-inflammatory and antioxidant properties, block the development of pathogenic microflora in the gastrointestinal tract of poultry, boost 
the secretion of gastric juice and promote better digestibility of animal feed. Hot pepper extract and capsaicin contained in it stimulates the generation of enzymes, which leads to better digestion and absorption of nutrients. Protected organic acids, including fumaric, sorbic, DL-malic acid, having an acidifying effect and working in synergy with essential oils, disorder the cell membranes of bacterial cells, acidify the cell medium and break its metabolism and stop reproduction. Complex action of phytobiotics and protected organic acids promotes the formation of a healthy microbiocenosis in the gastrointestinal tract of broiler-type chicken, providing high resistance to intestinal colonization by pathogens.

\section{References}

1. E.D. Dzhavadov, I.N. Vikhreva, T.T. Papazyan, S.V. Shchepetkina, N.I. Prokofyeva, N.V. Tarlavin, Ptitsevodstvo, 11, 41-46 (2017) (in Russian)

2. What does antibiotic resistance mean? URL: https://lechim-serdce.ru/2017/12/12/chtoznachit-ustoychivost-k-antibiotikam (in Russian)

3. E.R. Baymuratova, Spreading resistance of microorganisms to antimicrobial drugs is a global biological threat of the XXI century. Evaluation of the quality and safety of consumer products, Materials of the II all-Russian research and practice conference of young researchers, Irkutsk, 18-23 (2020) (in Russian).

4. U. Gadde, W.H. Kim, S.T. Oh, S. Lillehoj, Hyun Alternatives to antibiotics for maximizing growth performance and feed efficiency in poultry: a review, Animal Biosciences and Biotechnology Laboratory, Beltsville Agricultural Research Center, Agricultural Research Service (USDA, Beltsville, MD 20705, USA, 2017)

5. P. Kanardov, Tsenovik, 9, 22 (2017) (In Russian)

6. V.I. Fisinin, I.A. Yegorov, G.YU. Laptev, T.N. Lenkova, I.N. Nikonov, L.A. Ilina, et al., Voprosy pitaniya [Problems of nutrition], 6, 114-124 (2017) (In Russian)

7. E.V. Shatskikh, D.M. Galiyev, A.I. Nufer, Ptitsa i ptitseprodukty, 6, 26-29 (2019) (In Russian)

8. E.V. Shatskikh, A.I. Nufer, D.M. Galiyev, Ptitsevodstvo, 1, 31-36 (2020) (In Russian)

9. N.V. Yunyayeva, K.V. Salandayev, A.V. Slyusar, Ptitsevodstvo, 8, 43-45 (2016) (In Russian)

10. N.P. Buryakov, M.A. Buryakova, M.M. Mironov, Rossiyskiy veterinarnyy zhurnal, 1, 13 (2015) (In Russian)

11. O.A. Vasilyeva, A.I. Nufer, E.V. Shatskikh, Effektivnoye zhivotnovodstvo, 4, 66-68 2019 (In Russian) 